\title{
An Interview with Thomas J. Sargent*
}

\author{
George W. Evans \\ Department of Economics \\ University of Oregon \\ email: gevans@uoregon.edu \\ and \\ Seppo Honkapohja \\ Faculty of Economics and Politics \\ University of Cambridge \\ email: smsh4@cam.ac.uk
}

January 11, 2005

The rational expectations hypothesis swept through macroeconomics during the 1970's and permanently altered the landscape. It remains the prevailing paradigm in macroeconomics, and rational expectations is routinely used as the standard solution concept in both theoretical and applied macroeconomic modelling. The rational expectations hypothesis was initially formulated by John F. Muth Jr. in the early 1960s. Together with Robert Lucas Jr., Thomas (Tom) Sargent pioneered the rational expectations revolution in macroeconomics in the 1970s.

Possibly Sargent's most important work in the early 1970's focused on the implications of rational expectations for empirical and econometric research. His short 1971 paper "A Note on the Accelerationist Controversy" provided a dramatic illustration of the implications of rational expectations by demonstrating that the standard econometric test of the natural rate hypothesis was invalid. This work was followed in short order by key papers that

*This interview is forthcoming in Macroeconomic Dynamics. 
showed how to conduct valid tests of central macroeconomic relationships under the rational expectations hypothesis. Imposing rational expectations led to new forms of restrictions, called "cross-equation restrictions," which in turn required the development of new econometric techniques for the study of macroeconomic relations and models.

Tom's contributions were wide ranging. His early econometric work in the 1970s includes studies of the natural rate of unemployment, the neutrality of real interest rates with respect to money, dynamic labor demand, empirics of hyperinflation, and tests for the neutrality of money in "classical" rational expectations models. In the 1980s Sargent (with Lars Hansen) developed new econometric methods for estimating rational expectations models.

In addition to these seminal contributions to rational expectations econometrics, Sargent made several key contributions during this period to theoretical macroeconomics, including the saddle path stability characterization of the rational expectations equilibrium and the policy ineffectiveness proposition (both developed with Neil Wallace), and the observational equivalence of rational and non-rational theories of monetary neutrality. In later work Tom continued to extend the rational expectations equilibrium paradigm into new areas. Two prominent examples are the implications of the government budget constraint for inflation and "unpleasant monetarist arithmetic" (with Neil Wallace) and the sources of the European unemployment problem (with Lars Ljungqvist).

Tom's impact on macroeconomics in the early days of rational expectations extends well beyond this research. His 1979 textbook Macroeconomic Theory introduced a generation of graduate students around the world to a new vision of macroeconomics in which time series analysis is fully integrated into macro theory, and in which macroeconomic equilibrium is viewed as a stochastic process.

Sargent's contributions have not been confined to the development and application of the rational expectations paradigm. As a true scholar he became interested in the theoretical foundations of rationality. As he describes below, the initial criticisms of the concept of rational expectations led him in the 1980s to join a line of research called "learning theory," in which the theoretical underpinnings of rational expectations were examined.

Tom became one of the pioneers in this area as well. His 1989 papers with Albert Marcet showed how to use the tools of stochastic approximation to analyze convergence of least squares learning to rational expectations equilibrium in a general framework. His 1993 book Bounded Rationality in 
Macroeconomics helped to disseminate the learning approach to a broader audience, and was part of the rapid growth of research on learning in the 1990s. Tom's 1999 book The Conquest of American Inflation called attention to the possibility of "escape routes," i.e. occasional large deviations from an equilibrium, and led to a surge of interest in persistent learning dynamics. Closely related to the research on learning are issues of robustness and model misspecification to which Tom (with Lars Hansen) has recently made key contributions.

The depth and range of the contributions we have listed is huge, yet this is not the full extent. Sargent has also done important research in economic history. His work in the 1980s on episodes of moderate and rapid inflations and the recent research on monetary standards (with Francois Velde) is much less technical, but the rational expectations viewpoint remains clearly visible in these works.

Many collaborators, researchers and students have personally experienced Tom's remarkable intellectual depth and energy. His thinking is well reflected in this interview, which has a somewhat unusual format. It gets to the key issues very quickly. Only at the end is there commentary on some of his personal experiences as a scholar.

\section{Rational Expectations Econometrics}

Evans and Honkapohja: How did you first get interested in rational expectations?

Sargent: When I was a graduate student, estimating and interpreting distributed lags topped the agenda of macroeconomists and other applied economists. Because distributed lags are high dimensional objects, people like Solow, Jorgenson, Griliches, Nerlove, and Almon sought economical ways to parameterize those distributions in clever ways, for example, by using ratios of low order polynomials in a lag operator. As beautiful as they are, where on earth do those things come from? Cagan and Friedman interpreted their adaptive expectations geometric distributed lag as measuring people's expectations. At Carnegie, Mike Lovell told me to read John Muth's 1960 JASA paper. It rationalized Friedman's adaptive expectations model for permanent income by reverse engineering a stochastic process for income for which Cagan's expectation formula equals a mathematical expectation of future values conditioned on the infinite history of past incomes. Muth's message was that the stochastic process being forecast should dictate both 
the distributed lag and the conditioning variables that people use to forecast the future. The point about conditioning variables primed us to see the importance of Granger-Wiener causality for macroeconomics.

Evans and Honkapohja: When did you first use rational expectations to restrict a distributed lag or a vector autoregression in empirical work?

Sargent: In a 1971 paper on testing the natural unemployment rate hypothesis. I figured out the pertinent cross-equation restrictions and showed that in general they didn't imply the 'sum-of-the-weights' test on distributed lags that was being used to test the natural rate hypothesis. That was easy because for that problem I could assume that inflation was exogenous and use a univariate process for inflation. My 1973 and 1977 papers on rational expectations and hyperinflation tackled a more difficult problem. Those papers found the cross-equation restrictions on a VAR for money and prices by reverse engineering a joint process for which Cagan's adaptive expectations formula delivers optimal forecasts. This was worth doing because Cagan's model fit the data so well. Imposing rational expectations exposed a lot about the Granger causality structure between money and prices that prevailed during most of the hyperinflations that Cagan had studied.

Evans and Honkapohja: Econometrically, what was the big deal about rational expectations?

Sargent: Cross-equation restrictions and the disappearance of any free parameters associated with expectations.

Evans and Honkapohja: What do you mean 'disappearance'?

Sargent: In rational expectations models, people's beliefs are among the outcomes of our theorizing. They are not inputs.

Evans and Honkapohja: Do you think that differences among people's models are important aspects of macroeconomic policy debates?

Sargent: The fact is that you simply cannot talk about those differences within the typical rational expectations model. There is a communism of models. All agents inside the model, the econometrician, and God share the same model. The powerful and useful empirical implications of rational expectations - the cross-equation restrictions and the legitimacy of the appeal to a law of large number in GMM estimation - derive from that communism of models. 
Evans and Honkapohja: What role do cross-equation restrictions play in Lucas's Critique?

Sargent: They are everything. The positive part of Lucas's critique was to urge applied macroeconomists and econometricians to develop ways to implement those cross equation restrictions. His paper had three examples. What transcends them is their cross-equation restrictions, and the absence of free parameters describing expectations. In a nutshell, Lucas's critique of prerational expectations work was, "you have ignored cross equation restrictions, and they are all important for policy evaluation."

Evans and Honkapohja: What do those cross-equation restrictions have to say about the evidence in favor of coefficient volatility that Bob Lucas talked about in the first part of his 'Critique'?

Sargent: Little or nothing. Lucas used evidence of coefficient drift and add factors to bash the Keynesians, but as I read his paper, at least, he didn't claim to offer an explanation for the observed drift. His three examples are each time-invariant structures. Data from them would not have coefficient drift even if you fit one of those misspecified Keynesian models. So the connection of the first part of his paper to the second was weak.

Evans and Honkapohja: Do you feel that your work contributed to the Lucas critique?

Sargent: It depends what you mean by 'contribute'. Lucas attended a conference on rational expectations at the University of Minnesota in the spring of 1973. The day after the conference, I received a call from Pittsburgh. Bob had lost a manuscript and thought he might have left it at the conference. I went to the room in Ford Hall at which we had held the conference and found a folder with yellow sheets in it. I looked at the first few pages. It was Bob's Critique. I mailed the manuscript back to Bob. So, yes, I contributed to the Critique.

Evans and Honkapohja: What were the profession's most important responses to the Lucas Critique?

Sargent: There were two. The first and most optimistic response was complete rational expectations econometrics. A rational expectations equilibrium is a likelihood function. Maximize it.

Evans and Honkapohja: Why optimistic? 
Sargent: You have to believe in your model to use the likelihood function. It provides a coherent way to estimate objects of interest (preferences, technologies, information sets, measurement processes) within the context of a trusted model.

Evans and Honkapohja: What was the second response?

Sargent: Various types of calibration. Calibration is less optimistic about what your theory can accomplish because you'd only use it if you didn't fully trust your entire model, meaning that you think your model is partly misspecified or incompletely specified, or if you trusted someone else's model and data set more than your own. My recollection is that Bob Lucas and Ed Prescott were initially very enthusiastic about rational expectations econometrics. After all, it simply involved imposing on ourselves the same high standards we had criticized the Keynesians for failing to live up to. But after about five years of doing likelihood ratio tests on rational expectations models, I recall Bob Lucas and Ed Prescott both telling me that those tests were rejecting too many good models. The idea of calibration is to ignore some of the probabilistic implications of your model, but to retain others. Somehow, calibration was intended as a balanced response to professing that your model, though not correct, is still worthy as a vehicle for quantitative policy analysis.

Evans and Honkapohja: Why do you say "various types of calibration'?

Sargent: Different people mean and do different things by calibration. Some people mean 'use an extraneous estimator'. Take estimates from some previous study and pretend that they are known numbers. An obvious difficulty of this procedure is that often those extraneous estimates were prepared with an econometric specification that contradicts your model. Treating those extraneous parameters as known ignores the clouds of uncertainty around them, clouds associated with the estimation uncertainty conveyed by the original researcher, and clouds from the 'specification risk' associated with putting your faith in the econometric specification that another researcher used to prepare his estimates.

Other people, for example Larry Christiano and Marty Eichenbaum, by calibration mean GMM estimates using a subset of the moment conditions for the model and data set at hand. Presumably, they impose only a subset of the moment conditions because they trust some aspects of their model 
more than others. This is a type of robustness argument that has been pushed furthest by those now doing semiparametric GMM. There are ways to calculate the standard errors to account for vaguely specified or distrusted aspects of the model. By the way, these ways of computing standard errors have a min-max flavor that reminds one of the robust control theory that Lars Hansen and I are using.

Evans and Honkapohja: We know what question maximum likelihood estimates answers, and the circumstances under which maximum likelihood estimates, or Bayesian counterparts to them, have good properties. What question is calibration the answer to?

Sargent: The best answer I know is contained in work by Hansen and others on GMM. They show the sense in which GMM is the best way to estimate trusted features of a less than fully trusted model.

Evans and Honkapohja: Do you think calibration in macroeconomics was an advance?

Sargent: In many ways, yes. I view it as a constructive response to Bob's remark that 'your likelihood ratio tests are rejecting too many good models'. In those days, the rational expectations approach to macroeconomics was still being challenged by influential people. There was a danger that skeptics and opponents would misread those likelihood ratio tests as rejections of an entire class of models, which of course they were not. (The internal logic of the likelihood function as a complete model should have made that clear, but apparently it wasn't at the time!) The unstated case for calibration was that it was a way to continue the process of acquiring experience in matching rational expectations models to data by lowering our standards relative to maximum likelihood, and emphasizing those features of the data that our models could capture. Instead of trumpeting their failures in terms of dismal likelihood ratio statistics, celebrate the features that they could capture and focus attention on the next unexplained feature that ought to be explained. One can argue that this was a sensible response to those likelihood ratio tests. It was also a response to the scarcity of resources at our disposal. Creating dynamic equilibrium macro theories and building a time series econometrics suitable for estimating them were both big tasks. It was a sensible opinion that the time had come to specialize and to use a sequential plan of attack: let's first devote resources to learning how to create a range of compelling equilibrium models to incorporate interesting 
mechanisms. We'll be careful about the estimation in later years when we have mastered the modelling technology.

Evans and Honkapohja: Aren't applications of likelihood based methods in macroeconomics now making something of a comeback?

Sargent: Yes, because, of course, a rational expectations equilibrium is a likelihood function, so you couldn't ignore it forever. In the 1980s, there were occasions when it made sense to say, it is too difficult to maximize the likelihood function, and besides if we do, it will blow our model out of the water.' In the 2000s, there are fewer occasions when you can get by saying this. First, computers have gotten much faster, and the Markov Chain Monte Carlo algorithm, which can be viewed as a clever random search algorithm for climbing a likelihood function, or building up a posterior, is now often practical. Furthermore, a number of researchers have constructed rational expectations models with enough shocks and wedges that they believe it is appropriate to fit the data well with complete likelihood based procedures. Examples are the recent models of Otrok and Smets and Wouters. By using log-linear approximations, they can use the same recursive representation of a Gaussian likelihood function that we were using in the late 1970s and early 80 s.

Of course, for some nonlinear equilibrium models, it can be difficult to write down the likelihood. But there has been a lot of progress here thanks to Tony Smith, Ron Gallant, and George Tauchen and others, who have figured out ways to get estimates as good, or almost as good, as maximum likelihood. I like the Gallant-Tauchen idea of using moment conditions from the first-order conditions for maximizing the likelihood function of a well fitting auxiliary model whose likelihood function is easy to write down.

Evans and Honkapohja: Do you see any drawbacks to likelihood based approaches for macro models?

Sargent: Yes. For one thing, without leaving the framework, it seems difficult to complete a self-contained analysis of sensitivity to key features of a specification.

Evans and Honkapohja: Do you think that these likelihood based methods are going to sweep away GMM based methods that don't use complete likelihoods?

Sargent: No. GMM and other calibration strategies will have a big 
role to play whenever a researcher distrusts part of his specification and so long as concerns about robustness endure.

\section{Learning}

Evans and Honkapohja: Why did you get interested in non-rational learning theories in macroeconomics?

Sargent: Initially, to strengthen the case for and extend our understanding of rational expectations. In the 1970s, rational expectations was severely criticized because, it was claimed, it endowed people with too much knowledge about the economy. It was fun to be doing rational expectations macro in the mid 70s because there was lots of skepticism, even hostility, toward rational expectations. Critics claimed that an equilibrium concept in which everyone shared 'God's model' was incredible. To help meet that criticism, I enlisted in Margaret Bray's and David Kreps's research program. Their idea was to push agents' beliefs away from a rational expectations equilibrium, then endow them with learning algorithms and histories of data. Let them adapt their behavior in a way that David Kreps later called 'anticipated utility' behavior: here you optimize, taking your latest estimate of the transition equation as though it were permanent; update your transition equation; optimize again; update again; and so on. (This is something like 'fictitious play' in game theory. Kreps argues that while it is 'irrational', it can be a smart way to proceed in contexts in which it is difficult to figure out what it means to be rational. Kreps's Schwartz lecture has some fascinating games that convince you that his anticipated utility view is attractive.) Margaret Bray, Albert Marcet, Mike Woodford, you two, Xiaohong Chen and Hal White, and the rest of us wanted to know whether such a system of adaptive agents would converge to a rational expectations equilibrium. Together, we discovered a broad set of conditions on the environment under which beliefs converge. Something like a rational expectations equilibrium is the only possible limit point for a system with adaptive agents. Analogous results prevail in evolutionary and adaptive theories of games.

Evans and Honkapohja: What do you mean 'something like'?

Sargent: The limit point depends on how much prompting you give agents in terms of functional forms and conditioning variables. The early work in the least squares learning literature initially endowed agents with wrong coefficients, but with correct functional forms and correct conditioning variables. With those endowments, the systems typically converged to 
a rational expectations equilibrium. Subsequent work by you two, and by Albert Marcet and me, withheld some pertinent conditioning variables from agents, e.g., by prematurely truncating pertinent histories. We found convergence to objects that could be thought of as 'rational expectations equilibria with people conditioning on restricted information sets'. Chen and White studied situations in which agents permanently have wrong functional forms. Their adaptive systems converge to a kind of equilibrium in which agents' forecasts are optimal within the class of information filtrations that can be supported by the functional forms to which they have restricted agents.

Evans and Honkapohja: How different are these equilibria with subtly misspecified expectations from rational expectations equilibria?

Sargent: They are like rational expectations equilibria in many ways. They are like complete rational expectations equilibria in terms of many of their operating characteristics. For example, they have their own set of cross-equation restrictions that should guide policy analysis.

They are 'self-confirming' within the class of forecasting functions agents are allowed. They can also be characterized as having forecasting functions that are as close as possible to mathematical expectations conditioned on pertinent histories that are implied by the model, where proximity is measured by a Kullback-Leibler measure of model discrepancy (that is, an expected log likelihood ratio). If they are close enough in this sense, it means that it could take a very long time for an agent living within one of these equilibria to detect that his forecasting function could be improved.

However, suboptimal forecasting functions could not be sustained in the limit if you were to endow agents with sufficiently flexible functional forms, e.g., the sieve estimation strategies like those studied by Xiaohong Chen. Chen and White have an example in which a system with agents who have the ability to fit flexible functional forms will converge to a nonlinear rational expectations equilibrium.

Evans and Honkapohja: Were those who challenged the plausibility of rational expectations equilibria right or wrong?

Sargent: It depends on how generous you want to be to them. We know that if you endow agents with correct functional forms and conditioning variables, even then only some rational expectations equilibria are limit points of adaptive economies. As you two have developed fully in your book, other rational expectations equilibria are unstable under the learning dynam- 
ics and are eradicated under least squares learning. Maybe those unstable rational expectations equilibria were the only ones the critics meant to question, although this is being generous to them. In my opinion, some of the equilibria that least squares learning eradicates deserved extermination: for example, the 'bad' Laffer curve equilibria in models of hyperinflations that Albert Marcet and I, and Stan Fischer and Michael Bruno also, found would not be stable under various adaptive schemes. That finding is important for designing fiscal policies to stabilize big inflations.

Evans and Honkapohja: Are stability results that dispose of some rational expectations equilibria, and that retain others, the main useful outcome of adaptive learning theory?

Sargent: They are among the useful results that learning theory has contributed. But I think that the stability theorems have contributed something even more important than equilibrium selection. If you stare at the stability theorems, you see that learning theory has caused us to refine what we mean by rational expectations equilibria. In addition to the equilibria with 'optimal misspecified beliefs' that I mentioned a little while ago, it has introduced a type of rational expectations equilibrium that enables us to think about disputes involving different models of the economy in ways that we couldn't before.

Evans and Honkapohja: What do you mean?

Sargent: Originally, we defined a rational expectations equilibrium in terms of the 'communism of models' that I alluded to earlier. By 'model', I mean a probability distribution over all of the inputs and outcomes of the economic model at hand. Within such a rational expectations equilibrium, agents can have different information, but they share the same model. Learning theories in both macroeconomics and game theory have discovered that the natural limit points of a variety of least-squares learning schemes are what Kreps, Fudenberg, and Levine call 'self-confirming equilibria'. In a self-confirming equilibrium, agents can have different models of the economy, but they must agree about events that occur sufficiently often within the equilibrium. That restriction leaves agents free to disagree about offequilibrium outcomes. The reason is that a law of large numbers doesn't have enough chances to act on such infrequent events. In the types of competitive settings that we often use in macroeconomics, disagreement about offequilibrium-path outcomes among small private agents don't matter. Those 
private agents need only to predict distributions of outcomes along an equilibrium path. But the government is a large player. If it has the wrong model about off-equilibrium-path outcomes, it can make wrong policy choices, simply because it is wrong about the counterfactual thought experiments that go into solving a Ramsey problem, for example. No amount of empirical evidence drawn from within a self-confirming equilibrium can convince a government that it is wrong about its model, because its model is correct for all frequently observed events. To be motivated to change its model, the government must either experiment or listen to a new theorist. The theorist has to come up with a model that is observationally equivalent with the government's model for the old self confirming equilibrium outcomes, but that improves the analysis of counterfactuals relative to those outcomes.

Evans and Honkapohja: Are there interesting examples of this kind of thing occurring in the macroeconomy?

Sargent: You can tell a story that this is what Lucas was up to with his 1972 JET paper on the natural rate. If you alter Kydland and Prescott's 1977 version of Lucas's story a little, you can alter their timing protocol and reinterpret Kydland and Prescott's suboptimal time consistent equilibrium as a self-confirming equilibrium that could be improved with a better government model of off equilibrium path outcomes.

Evans and Honkapohja: Wasn't this part of your story in The Conquest of American Inflation?

Sargent: Yes.

Evans and Honkapohja: So it seems that you can talk about disagreements among models within a rational expectations framework if you extend the concept of rational expectations to mean 'self-confirming'.

Sargent: Yes. This is a nice feature of self-confirming equilibrium models. My reading of disputes about economic policy is that they are not merely struggles based on different information or different interests - which is all they could possibly reflect within a 'communist' rational expectations model. Some disputes over government policy originate in the fact that advocates have different models of the way the economy functions, and it can be difficult to criticize their models on empirical grounds because they fit the data from the prevailing equilibrium.

Evans and Honkapohja: What else has learning theory contributed? 
Sargent: A couple of important things. First, it contains some results about rates of convergence to a rational expectations equilibrium that can be informative about how difficult it is to learn an equilibrium. Second, we have discovered that even when convergence occurs with probability one, sample paths can exhibit exotic trajectories called 'escape routes'. These escape routes exhibit long-lived departures from a self-confirming equilibrium and can visit objects that qualify as 'near equilibria'. The escape paths can be characterized by an elegant control problem and contribute a form of 'near rational' dynamics that can have amazing properties. I first encountered these ideas while working on my Conquest book. In-Koo Cho and Noah Williams have pushed these ideas further. I suspect that these escape routes will prove to be a useful addition to our toolkit. For example, they can sustain the kind of drifting parameters that Lucas brought out in the first part of his Critique, but that, until recently, most of us have usually refrained from interpreting as equilibrium outcomes. A good example of the type of phenomena that drifting coefficients with escapes from a self-confirming equilibrium can explain is contained in the recent AER paper on recurrent hyperinflations by Albert Marcet and Juan Pablo Nicolini.

Evans and Honkapohja: With your co-author Tim Cogley, you have been studying drifting coefficients and volatilities. Did Lucas's Critique fuel your work with Cogley?

Sargent: Yes. Sims claims that while there is ample evidence for drifting volatilities, the evidence for drifting coefficients is weak. And he uses that fact to argue that U.S. data are consistent with time-invariant government monetary and fiscal policy rules throughout the post WWII period. So when bad macroeconomic outcomes occurred, it was due to bad luck in the form of big shocks, not bad policy in the form of decision rules that had drifted into becoming too accommodating or too tight. It is true that detecting drifts in the AR coefficients in a VAR is much more difficult than detecting drifts in innovation volatilities - this is clearest in continuous time settings that finance people work in. (Lars Hansen has taught this to me in the context of our work on robustness.) Thus, Sims and other 'bad luck, not bad policy' advocates say that the drift spotted by Lucas is misinterpreted if it is regarded as indicating drifting decision rules, e.g., drifting monetary policy rules. The reason is that, by in effect projecting in wrong directions, it misreads stochastic volatility as reflecting drift in agents' decision rules. These are obviously very important issues that 
can be sorted out only with an econometric framework that countenances both drifting coefficients and drifting volatilities. Tim and I are striving to sort these things out, and so are Chris and Tao Zha and Fabio Canova.

\section{Economic History}

Evans and Honkapohja: Your papers on monetary history look very different than your other work. Why are there so few equations and so little formal econometrics in your writings on economic history? Like your 'Ends of Four Big Inflations' and your paper with Velde on features of the French Revolution? We don't mean to insult you, but you look more like an 'old economic historian' than a 'new economic historian'.

Sargent: This is a tough question. I view my efforts in economic history as pattern recognition, or pattern imposition, exercises. You learn a suite of macroeconomic models that sharpen your mind by narrowing it. The models alert you to look for certain items, e.g., ways that monetary and fiscal policy are being coordinated. Then you read some history and economic history and look at a bunch of error-ridden numbers. Data are often error-ridden and incomplete. You read contemporaries who say diverse things about what is going on, and historians who put their own spins on things. From this disorder, you censor some observations, overweight others. Somehow, you impose order and tell a story, cast in terms of the objects from your suite of macroeconomic theories. Hopefully, the story rings true.

Evans and Honkapohja: Do you find rational expectations models useful for understanding history?

Sargent: Yes. A difficult thing about history is that you are tempted to evaluate historical actors' decisions with too much hindsight. To understand things, you somehow have to put yourself in the shoes of the historical actor and reconstruct the information he had, the theory he was operating under, and the interests he served. Accomplishing this is an immense task. But our rational expectations theories and decision theories are good devices for organizing our analysis. By the way, to my mind, reading history immediately drives you away from perfect foresight models toward models in which people face non-trivial forecasting problems under uncertainty.

Evans and Honkapohja: Interesting. But you didn't answer our question about why your historical work is more informal than your other work. 
Sargent: I don't know. Most of the historical problems that I have worked on have involved episodes that can be regarded as transitions from one rational expectations equilibrium to another. For example, the ends of hyperinflations; the struggles for new monetary and fiscal policies presided over by Poincare and Thatcher; the directed search for a new monetary and fiscal constitution by a sequence of decision makers during the French revolution; the eight hundred year co-evolution of theories and policies and technologies for producing coins in our work with François on small change. I saw contesting theories at play in all of these episodes. We didn't see our way clear to being as complete and coherent as you have to be in formal work without tossing out much of the action. Analyzing the kinds of the transitions that we studied in formal terms would have required a workable model of the social process of using experience to induce new models, paradigm shifts and revolutions of ideas, the really hard unsolved problem that underlies Kreps's anticipated utility program. (You wouldn't be inspired to take Muth's brilliant leap to rational expectations models by running regressions.) We didn't know how to make such a model, but we nevertheless cast our narratives in terms of a process that, with hindsight, induced new models from failed experiences with old ones.

\section{Robustness and Model Misspecification}

Evans and Honkapohja: You work with Hansen and others on robust control theory. How is that work related to your work on rational expectations and on learning?

Sargent: It is connected to both, and to calibration as well. The idea is to give a decision maker doubts about his model and ask him to make good decisions when he fears that some other model might actually generate the data.

Evans and Honkapohja: Why is that a good idea?

Sargent: One loose motivation for both rational expectations theory and learning theories is that the economist's model should have the property that the econometrician cannot do better than the agents inside the model. This criterion was used in the old days to criticize the practice of attributing to agents adaptive and other naive expectations schemes. So rational expectations theorists endowed agents with the ability to form conditional expectations, i.e., take averages with respect to infinite data samples drawn 
from within the equilibrium. The idea of learning theory was to take this 'take averages' idea seriously by giving agents data from outside the equilibrium, then to roll up your sleeves and study whether and at what rate agents who take averages from finite outside-equilibrium data sets can eventually learn what they needed to know in a population rational expectations equilibrium. It turned out that they could. The spirit was to "make the agents like econometricians'.

Of course, the typical rational expectations model reverses the situation: the agent knows more than the econometrician. The agent inside the model knows the parameters of the true model while the econometrician does not and must estimate them. Further, thorough rational expectations econometricians often come away from their analyses with a battery of specification tests that have brutalized their models. (Recall my earlier reference to Bob's and Ed's early 1980s comments to me that 'your likelihood ratio tests are rejecting too many good models.')

Using robust control theory is a way to let our agents share the experiences of econometricians. The idea is to make the agent acknowledge and cope with model misspecification.

Evans and Honkapohja: Is this just to make sure that agents are put on the same footing as us in our role as econometricians?

Sargent: Yes. And an agent's response to fear of model misspecification contributes behavioral responses that have interesting quantitative implications. For example, fear of model misspecification contributes components of indirect utility functions that in some types of data can look like heightened risk aversion, but that are actually responses to very different types of hypothetical mental experiments than are Pratt measures of risk aversion. For this reason, fear of model misspecification is a tool for understanding a variety of asset price spreads. Looked at from another viewpoint, models of robust decision making contribute a disciplined theory of what appears to be an endogenous preference shock.

Another reason is that decision making in the face of fear of model misspecification can be a useful normative tool for solving Ramsey problems. That is why people at central banks are interested in the topic. They distrust their models.

Evans and Honkapohja: What are some of the connections to learning theory? 
Sargent: There are extensive mathematical connections through the theory of large deviations. Hansen and I exploit these. Some misspecifications are easy to learn about, others are difficult to learn about. By 'difficult' I mean 'learn at a slow rate'. Large deviation theory tells us which misspecifications can be learned about quickly and which can't. Hansen and I restricted the amount of misspecification that our agent wants to guard against by requiring that it be a misspecification that is hard to distinguish from his approximating model. This is how we use learning theory to make precise what we mean by the phrase 'the decision maker thinks his model is a good approximation'. There is a race between a discount factor and a learning rate. With discounting, it makes sense to try to be robust against plausible alternatives that are difficult to learn about.

Evans and Honkapohja: Can this model of decision making be recast in Bayesian terms?

Sargent: It depends on your perspective. We have shown that ex post, it can, in the sense that you can come up with a prior, a distorted model, that rationalizes the decision maker's choices. But ex ante you can't - the set of misspecifications that the agent fears is too big and he will not or cannot tell you a prior over that set.

By the way, Lars and I have constructed equilibria with heterogeneous agents in which the ex post Bayesian analysis implies that agents with different interests will have different 'twisted models'. From the point of view of a rational expectations econometrician, these agents look as if they have different beliefs. This is a disciplined way of modelling belief heterogeneity.

Evans and Honkapohja: Is this a type of behavioral economics or bounded rationality?

Sargent: Any decision theory is a type of behavioral economics. It is not a type of bounded rationality. The decision maker is actually smarter than a rational expectations agent because his fear of model misspecification is out in the open.

Evans and Honkapohja: Parts of your description of robustness remind us of calibration? Are there connections?

Sargent: I believe there are, but they are yet to be fully exploited. Robust versions of dynamic estimation problems have been formulated. In these problems, the decision maker does not use standard maximum likelihood estimators for his approximating model - he distrusts his likelihood 
function. Therefore, he distorts his likelihood function in preparing his estimates. This twisting is reminiscent of what some calibrators do, though the robustness procedure is more precisely defined, in the sense that you can answer your earlier question about 'what question is calibration the answer to?'

Evans and Honkapohja: Why has Sims criticized your work on robustness?

Sargent: He thinks it is not wise to leave the Bayesian one-model framework of Savage. He thinks that there are big dividends in terms of ease of analysis by working hard to represent fear of model misspecifications in ways that stay within the Bayesian framework.

However, I should say that Lars's and my readings of Chris's early work on approximation of distributed lags were important inspirations for our work on robustness. Chris authored a beautiful approximation error formula and showed how to use it to guide the choice of appropriate data filters that would minimize approximation errors. That beautiful practical analysis of Chris's had a min-max flavor and was not self-consciously Bayesian. One version of Chris's min-max analysis originated in a message that Chris wrote to me about a comment in which I had argued that a rational expectations econometrician should never use seasonally adjusted data. My argument was very Bayesian in spirit, because I assumed that the econometrician had the correct model. Chris both read my comment and wrote his memo on a Minneapolis bus going home from the U in 1976 - that's how fast Chris is. Chris's bus-memo on seasonality and approximation error was pretty well known in the macro time series community at Minnesota in the late 1970s. (At the time, I don't know why, I felt that the fact that Chris could write such an insightful memo while riding on his twenty minute bus ride home put me in my proper place.) By the way, in Eric Ghysels's 1993 Journal of Econometrics special volume on seasonality, Lars and I wrote a paper that went a long way towards accepting Sims's bus memo argument. That Ghysels volume paper was one motivation for our robustness research agenda.

\section{Minnesota economics}

Evans and Honkapohja: Along with Carnegie-Mellon and Chicago, Minnesota during the 1970s was at the forefront in developing and propagating a new dynamic macroeconomics. What ingredients formed the Minnesota environment? 
Sargent: Tension and tolerance. We took strong positions and had immense disagreements. But the rules of engagement were civil and we always built each other up to our students. Minnesota in those days had a remarkable faculty. (It still does!) The mature department leaders Leo Hurwicz and John Chipman set the tone: they advocated taking your time to learn carefully and they encouraged students to learn math. Chris Sims and Neil Wallace were my two best colleagues. Both were forever generous with ideas, always extremely critical, but never destructive. The three of us had strong disagreements but there was also immense respect. Our seminars were exciting. I interacted intensively with both Neil and Chris through dissertations committees.

The best thing about Minnesota from the mid 70s to mid 80s was our extraordinary students. These were mostly people who weren't admitted into top 5 schools. Students taking my macro and time series classes included John Geweke, Gary Skoog, Salih Neftci, George Tauchen, Michael Salemi, Lars Hansen, Rao Aiyagari, Danny Peled, Ben Bental, Bruce Smith, Michael Stutzer, Charles Whiteman, Robert Litterman, Zvi Eckstein, Marty Eichenbaum, Yochanan Shachmurove, Rusdu Saracoglu, Larry Christiano, Randall Wright, Richard Rogerson, Gary Hansen, Selahattin Imrohoroglu, Ayse Imrohoroglu, Fabio Canova, Beth Ingram, Bong Soo Lee, Albert Marcet, Rodolfo Manuelli, Hugo Hopenhayn, Lars Ljungqvist, Rosa Matzkin, Victor Rios Rull, Gerhard Glomm, Ann Vilamil, Stacey Schreft, Andreas Hornstein, and a number of others. What a group! A who's-who of modern macro and macroeconometrics. Even a governor of a central bank (Rusdu Saracoglu)! If these weren't enough, after I visited Cambridge, Massachusetts in 1981-82, Patrick Kehoe, Danny Quah, Paul Richardson, and Richard Clarida each came to Minneapolis for much of the summer of 1982, and Danny and Pat stayed longer as RAs. It was a thrill teaching classes to such students. Often I knew less than the students I was 'teaching'. Our philosophy at Minnesota was that we teachers were just more experienced students.

One of the best things I did at Minnesota was to campaign for us to make an offer to Ed Prescott. He came in the early 1980s and made Minnesota even better.

Evans and Honkapohja: You make 1970s-1980s Minnesota sound like a love-in among Sims and Wallace and you. How do you square that attitude with the dismal view of your work expressed in Neil Wallace's JME review of your Princeton book on the history of small change with François 
Velde? Do friends write about each other that way?

Sargent: Friends do talk to each other that way. Neil thinks that cashin-advance models are useless and gets ill every time he sees a cash-in-advance constraint. For Neil, what could be worse than a model with a cash-inadvance constraint? A model with two cash-in-advance constraints. But that is what Velde and I have! The occasionally positive multiplier on that second cash-in-advance constraint is Velde and my tool for understanding recurrent shortages of small change and upward drifting prices of large denomination coins in terms of small denomination ones.

When I think of Neil, one word comes to mind: integrity. Neil's evaluation of my book with Velde was no worse than his evaluation of the papers that he and I wrote together. Except for our paper on commodity money, not our best in my opinion, Neil asked me to remove his name from every paper that he and I wrote together.

Evans and Honkapohja: Was he being generous?

Sargent: I don't think so. He thought the papers should not be published. After he read the introduction to one of our JPE papers, Bob Lucas told me that no referee could possibly say anything more derogatory about our paper than what we had written about it ourselves. Neil wrote those critical words. 


\section{Selected Scientific Publications of Thomas J. Sargent}

\section{1}

"A Note on the Accelerationist Controversy," Journal of Money, Credit and Banking, 3:3, Aug., 1971, p. 721-25.

\section{3}

"The Stability of Models of Money and Growth with Perfect Foresight," (with Neil Wallace), Econometrica, 41:6, Nov., 1973, p. 1043-48.

"Interest Rates and Prices in the Long Run: A Study of the Gibson Paradox," Journal of Money, Credit and Banking, 5:1, part 2, Feb., 1973, p. 385-449.

"Rational Expectations and the Dynamics of Hyperinflation," (with Neil Wallace), International Economic Review, 14:2, June, 1973, p. 328-50.

"Rational Expectations, the Real Rate of Interest, and the Natural Rate of Unemployment," Brookings Papers on Economic Activity, 1973:2, p. 429-72.

\section{4}

"The Elasticity of Substitution and the Cyclical Behavior of Productivity, Wages, and Labor's Share," (with Neil Wallace), American Economic Review, 64:2, May, 1974, p. 257-63.

\section{5}

"Rational Expectations, the Optimal Monetary Instrument, and the Optimal Money Supply Rule," (with Neil Wallace), Journal of Political Economy, 83:2, April, 1975, p. 241-54.

\section{6}

"A Classical Macroeconometric Model of the United States," Journal of Political Economy, 84:2, April, 1976, p. 207-37.

"The Observational Equivalence of Natural and Unnatural Rate Theories of Macroeconomics," Journal of Political Economy, 84:3, June, 1976, p. 631-40.

"Econometric Exogeneity and Alternative Estimators of Portfolio Balance for Hyperinflations: a Note," Journal of Monetary Economics, 2:4, Nov., 1976, p. $511-21$. 
"The Demand for Money During Hyperinflations Under Rational Expectations, I," International Economic Review, 18:1, Feb., 1977, p. 59-82.

"Business Cycle Modeling Without Pretending to Have Too Much a Priori Economic Theory," (with C.A. Sims) in: New Methods in Business Cycle Research: Proceedings From a Conference, Federal Reserve Bank of Minneapolis, October, 1977, p. 45-109.

\section{8}

"Seasonality and Portfolio Balance Under Rational Expectations," (with R. Saracoglu), Journal of Monetary Economics, 4:3, Aug., 1978, p. 435-58.

"A Little Bit of Evidence on the Natural Rate Hypothesis from the U.S." (with S. Neftci), Journal of Monetary Economics, 4:2, April, 1978, p. 315-19.

"Estimation of Dynamic Labor Demand Schedules Under Rational Expectations," Journal of Political Economy, 86:6, Dec., 1978, p. 1009-44.

Comment on K. Wallis' "Seasonal Adjustment and Multiple Time Series Analysis," in: Seasonal Analysis of Economic Time Series, ed. by Arnold Zellner, U.S. Department of Commerce, Dec., 1978, p. 361-64.

\section{9}

"A Note on Maximum Likelihood Estimation of the Rational Expectations Model of The Term Structure," Journal of Monetary Economics 5:1, Jan., 1979, p. 133-43.

"After Keynesian Macroeconomics," (with R.E. Lucas, Jr.), Federal Reserve Bank of Minneapolis Quarterly Review, 3:2, Spring, 1979. p. 1-16.

Macroeconomic Theory, Academic Press.

1980

"Tobin's 'q' and the Rate of Investment in General Equilibrium," in On The State of Macroeconomics, (Carnegie-Rochester No. 12) ed. by K. Brunner and A. Meltzer, North-Holland, 1980, p. 107-54.

"Formulating and Estimating Dynamic Linear Rational Expectations Models," (with L.P. Hansen), Journal of Economic Dynamics and Control, 2:1, Feb., 1980, p. 7-46. 
"Interpreting Economic Time Series," Journal of Political Economy, 89:2, April, 1981, p. 213-48.

"A Note on Wiener-Kolmogorov Prediction Formulas for Rational Expectations Model," (with L.P. Hansen), Economics Letters, 8:3, 1981, p. 255-60.

"Linear Rational Expectations Models of Dynamically Interrelated Variables," (with L.P. Hansen), in: Rational Expectations and Econometric Practice, University of Minnesota Press, 1981, Vol. 1, p. 127-56.

"Rational Expectations and Econometric Practice," (with R.E. Lucas, Jr.), Introductory Essay to: Rational Expectations and Econometric Practice, University of Minnesota Press, 1981, p. xi-x1.

"Some Unpleasant Monetarist Arithmetic," (with N. Wallace), Federal Reserve Bank of Minneapolis Quarterly Review, 5:3, Fall, 1981, p. 1-17.

\section{2}

"Beyond Supply and Demand Curves in Macroeconomics," American Economic Review, 72:2, May, 1982, p. 382-89.

"Instrumental Variables Procedures for Estimating Linear Rational Expectations Model," (with L.P. Hansen), Journal of Monetary Economics, 9:3, May, 1982, p. 263-96.

"The Real Bills Doctrine vs. the Quantity Theory: A Reconsideration," (with N. Wallace), Journal of Political Economy, 90:6, Dec., 1982, p. 121236 .

\section{3}

"Stopping Moderate Inflations: The Methods of Poincaré and Thatcher," in: Inflation, Debt and Indexation, ed. by R. Dornbusch and M. Simonsen, MIT Press, 1983, p. 54-98.

"The Ends of Four Big Inflations," in: Inflation: Causes and Effects, ed. by Robert E. Hall, University of Chicago Press, for the NBER, 1983, p. 41-97.

"A Model of Commodity Money," (with N. Wallace), Journal of Monetary Economics, 12:1, July, 1983, p. 163-87.

"The Dimensionality of the Aliasing Problem in Models With Rational Spectral Densities," (with L.P. Hansen), Econometrica, 51:2, Mar., 1983, p. 37788. 
"Aggregation Over Time and the Inverse Optimal Predictor Problem for Adaptive Expectations in Continuous Time," (with L.P. Hansen), International Economic Review, 24:1, Feb., 1983, p. 1-20.

\section{4}

"Autoregressions, Expectations, and Advice," American Economic Review, 74:2, May, 1984, p. 408-420.

\section{5}

"Interest on Reserves," (with N. Wallace), Journal of Monetary Economics, 15:3, May, 1985, p. 279-90.

Rational Expectations and Inflation, Harper and Row.

\section{7}

"Inflation and the Government Budget Constraint," (with Neil Wallace), in Economic Policy in Theory and Practice, ed. by Assaf Razin and Efraim Sadka, MacMillan Press, London, 1987.

"Irrelevance of Open-Market Operations in Some Economies With Government Currency Being Dominated in Rate of Return," (with Bruce D. Smith), American Economic Review, March 1987.

Dynamic Macroeconomic Theory, Harvard University Press.

\section{9}

"Two Models of Measurements and the Investment Accelerator," Journal of Political Economy, 1989, vol. 97, no. 2.

"Least Squares Learning and the Dynamics of Hyperinflation," (with Albert Marcet) in Sunspots, Complexity, and Chaos, ed. by W. Barnett, J. Geweke and K. Shell, Cambridge University Press, 1989.

"Convergence of Least Squares Learning in Environments with Hidden State Variables and Private Information," (with Albert Marcet), Journal of Political Economy, vol. 97, no. 6, 1989.

"Convergence of Least Squares Learning Mechanisms in Self-Referential Linear Stochastic Models," (with Albert Marcet), Journal of Economic Theory, vol. 48, no. 2, August 1989.

"Interpreting New Evidence About China and U.S. Silver Purchases," (with Loren Brandt), Journal of Monetary Economics, Jan. 1989. 


\section{0}

"Money as a Medium of Exchange in an Economy With Artificially Intelligent Agents," (with Ramon Marimon, and Ellen McGrattan), in Journal of Economic Dynamics and Control, no. 14, 1990.

"The Analytics of German Monetary Reform", with François Velde, Federal Reserve Bank of San Francisco Quarterly Review, fall 1990.

\section{1}

Rational Expectations Econometrics, with Lars Peter Hansen, Westview Press. "Equilibrium with Signal Extraction from Endogenous Variables," Journal of Economic Dynamics and Control, 1991.

\section{3}

"Seasonality and Approximation Errors in Rational Expectations Models," (with Lars Hansen) Journal of Econometrics, vol. 55, 1993, pp. 21-55.

"On the Preservation of Deterministic Cycles when Some Agents Perceive them to be Random Fluctuations," (with George Evans and Seppo Honkapohja), in Journal of Economic Dynamics and Control, vol. 17, 1993, p. 705721.

Bounded Rationality in Macroeconomics, Oxford University Press.

\section{5}

"Macroeconomic Features of the French Revolution," (with François Velde), in Journal of Political Economy, vol. 103, June 1995, pp. 474-518.

"Discounted Linear Exponential Quadratic Gaussian Control," (with Lars P. Hansen), in IEEE Transactions on Automatic Control, vol.40, May 1995, pp. 968-971.

"The Swedish Unemployment Experience," (with Lars Ljungqvist), in European Economic Review, 39, 1995, pp. 1043-1070.

"Welfare States and Unemployment," (with Lars Ljungqvist), in Economic Theory, 6, 1995, pp. 143-160.

"Speed of Convergence of Recursive Least Squares Learning with ARMA Perceptions," in Learning and Rationality in Economics, eds. (with Albert Marcet) in Learning and Rationality in Economics, Alan Kirman and Mark Salmon. Basil Blackwell, Oxford, 1995. 


\section{6}

"Mechanics of Forming and Estimating Dynamic Linear Economies," (with Evan Anderson, Lars P. Hansen, and Ellen McGrattan), in Handbook of Computational Economics, edited by John Rust, 1996. North Holland.

"Neural Networks for Encoding and Adapting in Dynamic Economies," (with In-Koo Cho), in Handbook of Computational Economics, edited by John Rust, 1996. North Holland.

\section{7}

"Accounting Properly for the Government's Interest Costs," (with George Hall), Federal Reserve Bank of Chicago Economic Perspectives. 1997, vol. 21, no. 4, 18-28.

"Two Computations to Fund Social Security," (with He Huang and Selahattin Imrohoroglu), Macroeconomic Dynamics, 1997, vol. 1, no. 1, 7-44.

"Coinage, Debasements, and Gresham's Laws," (with Bruce Smith), Economic Theory, August 1997, vol. 10, no. 2, 197-226.

\section{8}

"The European Unemployment Dilemma," (with Lars Ljungqvist), Journal of Political Economy, June, 1998, vol 106, n3, 514-50.

\section{9}

The Conquest of American Inflation, Princeton University Press, 1999.

"Projected U. S. Demographics and Social Security," (with Mariacristina De Nardi and Selahattin Imrohoroglu), Review of Economic Dynamics, Volume 2, 1999, pp. 575-616.

"Robust Permanent Income and Pricing" (with Lars Hansen and Thomas Tallarini, Jr.), Review of Economic Studies, Vol 66, 1999, pp. 873-907.

\section{0}

Recursive Macroeconomomic Theory, with Lars Ljungqvist, MIT press.

\section{1}

"Evolving Post-World War II U.S. Inflation Dynamics," (with Timothy Cogley), in Macroeconomic Annual, 2001, ed. Ben Bernanke and Kenneth Rogoff.

"Acknowledging Misspecification in Macroeconomic Theory," (with Lars Hansen), Review of Economic Dynamics, Vol. 4, No. 3, July 2001, pp. 519-535. 


\section{2}

The Big Problem of Small Change, with François Velde, Princeton University Press, 2002.

"Optimal Taxation without State Contingent Debt," (with Rao Aiyagari, Albert Marcet and Juha Seppala), Journal of Political Economy, December 2002.

"Robust and Pricing with Uncertain Growth," (with Marco Cagetti, Lars Peter Hansen, and Noah Williams), Review of Financial Studies, 15(2): pp. 363-404, March 2002.

"Robust Permanent Income and Pricing with Filtering," (with Lars Peter Hansen and Neng Wang), Macroeconomic Dynamics, 6, pp. 40-84, February 2002.

"Escaping Nash Inflation," (with In-Koo Cho and Noah Williams), Review of Economic Studies, 69: 1-40, January 2002.

\section{3}

"European Unemployment: From a Worker's Perspective," (with Lars Ljungqvist), in Knowledge, Information, and Expectations, in Modern Macroeconomics in Honor of Edmund S. Phelps, edited by Philippe Aghion, Roman Frydman, Joseph Stiglitz, and Michael Woodford, Princeton University Press, 2003.

"Robust Control of Forward Looking Models," (2003), (with Lars Peter Hansen), Journal of Monetary Economics, April, 50(3): 581-604.

"A Quartet of Semigroups for Model Specification, Robustness, Prices of Risk, and Model Detection, " (with Evan Anderson and Lars Peter Hansen), Journal of the European Economic-Association. March 2003; 1(1): 68-123.

\section{4}

Recursive Macroeconomic Theory, Second Edition, MIT press.

"Lotteries for consumers versus lotteries for firms," (2004) (with Lars Ljungqvist), Frontiers in Applied General Equilibrium Modeling, edited by Timothy J. Kehoe, T. N. Srinivasan and John Whalley. Cambridge University Press.

"European Unemployment and Turbulence Revisited in a Matching Model," (2004), (with Lars Ljungqvist), Journal of the European Economic-Association, April-May, 2(2-3), pp. 456-468. 